\title{
CHANGING THE PRICE OF MARRIAGE: EVIDENCE FROM BLOOD TEST REQUIREMENTS
}

\author{
Kasey S. Buckles \\ Melanie E. Guldi \\ Joseph Price \\ Working Paper 15161 \\ http://www.nber.org/papers/w15161
NATIONAL BUREAU OF ECONOMIC RESEARCH
1050 Massachusetts Avenue
Cambridge, MA 02138 \\ July 2009
}

We gratefully acknowledge the helpful comments of Bill Evans, Hilary Hoynes, Dan Hamermesh, and Martha Bailey, along with participants at seminars at UC-Merced, the University of Connecticut, Baylor University, University of Miami, the Five Colleges Junior Faculty Seminar, and the annual meetings of SOLE and the PAA. Amanda Deckelman, Elizabeth Munnich, and Michelle Zagardo provided terrific research assistance and Scott Cunningham shared his data on STD rates. The views expressed herein are those of the author(s) and do not necessarily reflect the views of the National Bureau of Economic Research.

NBER working papers are circulated for discussion and comment purposes. They have not been peerreviewed or been subject to the review by the NBER Board of Directors that accompanies official NBER publications.

(C) 2009 by Kasey S. Buckles, Melanie E. Guldi, and Joseph Price. All rights reserved. Short sections of text, not to exceed two paragraphs, may be quoted without explicit permission provided that full credit, including $\odot$ notice, is given to the source. 
Changing the Price of Marriage: Evidence from Blood Test Requirements

Kasey S. Buckles, Melanie E. Guldi, and Joseph Price

NBER Working Paper No. 15161

July 2009

JEL No. J12,K36

\begin{abstract}
$\underline{\text { ABSTRACT }}$
We use state repeals of blood test requirements for a marriage license that occurred between 1980 and 2005 to examine the impact of changes in the price of marriage on the marriage decision. Using a within-group estimator that holds constant state and year effects and exploits variation in the repeal dates of BTRs across states, we find that BTRs are associated with a 5.7\% decrease in marriage licenses issued by a state. Using individual-level marriage license data from 1981-1995, we find that about half of this effect is due to couples seeking marriage licenses in other states, with the other half is due to deterred marriages. We also examine the marital status of mothers using birth certificate and Current Population Survey data, and find that blood test requirements reduce the fraction of first-time mothers who are married at the time of birth. The marriage-deterrent effects of BTRs are larger for lower socio-economic groups.
\end{abstract}

Kasey S. Buckles

Dept. of Economics \& Econometrics

University of Notre Dame

436 Flanner Hall

Notre Dame, IN 46556

kbuckles@nd.edu

Melanie E. Guldi

Mount Holyoke College

Department of Economics

50 College Street

South Hadley, MA 01075

mguldi@mtholyoke.edu
Joseph Price

Department of Economics

Brigham Young University

162 FOB

Provo, UT 84602

and NBER

joseph_price@byu.edu 


\section{Introduction}

Marriage has been shown to be positively related to a number of important outcomes such as higher earnings and productivity, (Ahituv and Lerman, 2007; Korenman and Neumark, 1991), health (Clarka and Etileb, 2006; Duncan, Wilkerson, and England, 2006; Frech and Williams, 2007; Kenney and McLanahan, 2006; Liu and Umberson, 2008), better early child cognitive outcomes (Liu and Heiland, forthcoming), longevity (Felder, 2006), and higher self-reported happiness (Blanchflower and Oswald, 2004; Zimmerman and Easterlin, 2006). ${ }^{1}$ As such, researchers have long been interested in how individuals respond to changes in the cost of marriage, with some emphasis on the effects of public policy on the decision to marry. Policies that have been shown to affect the likelihood of marriage include those that relate to the marriage contract directly (such as minimum age requirements and divorce laws) and those that affect couples' economic incentives to marry (such as income taxes or transfer programs).

In this paper, we examine the decision to marry in response to a policy that has not been previously studied—blood test requirements (BTRs) for obtaining a marriage license. The BTRs we consider were enacted in the first half of the twentieth century as part of public health campaigns to reduce the spread of communicable diseases and prevent birth defects (Brandt 1985). The laws required couples applying for a marriage license to be screened for certain conditions, commonly rubella or syphilis. However, after penicillin proved to be a cheap and effective treatment for syphilis and vaccines were developed for rubella, these screenings were no longer considered cost-effective. In

\footnotetext{
${ }^{1}$ Most studies find that marriage is correlated with positive outcomes. However, the marriage wage penalty for white women is a notable exception (Waite 1995).
} 
1980, thirty-four states required a blood test in order to receive a marriage license.

Nineteen states repealed their laws in the 1980s, and by 2006 only Mississippi, Montana, and the District of Columbia still required premarital blood tests. ${ }^{2}$

We investigate the effects of the repeals of the BTRs on the marriage decision. This is an interesting case to consider for several reasons. First, the state law changes occurred in thirty-one states over a wide window of time (1980-2005). This provides significant variation and will allow us to separate the effect of the law change and overall shifts in marriage rates. Second, while we will be interested in whether the effects of the policy vary by socio-economic status or demographic group, the policy itself affected the entire population eligible for marriage in the state. Thus, the "treated" population in our study is much larger than in previous studies of minimum age requirements or tax and transfer policies, for example. Third, the repeals provide an opportunity to study the effects of a relatively small change in the cost of getting married. The results may be of interest to policy makers considering other policies that directly (required premarital counseling, waiting periods, and license fees) or indirectly (tax and transfer programs) affect the cost of getting married.

There are several ways that a BTR might increase the cost of getting married and induce couples to either obtain their license in another state or decide not to marry at all. First, the act of submitting to a blood test and waiting for results induces a waiting period for a marriage license that might deter spur-of-the-moment marriages. Also, since blood tests are usually paid for by the individual wishing to be married, the BTR increases the dollar cost of marriage. There are also likely to be other non-pecuniary costs associated

\footnotetext{
${ }^{2}$ Montana went on to repeal its requirement in 2007.
} 
with going to the doctor and having blood drawn or the potential cost of testing positive for and having to reveal that condition to one's partner. These costs might be a greater financial burden for certain populations, including those with lower income and lower education levels.

We first examine panel data on state marriage rates (obtained from the CDC and defined as marriage licenses issued per 1,000 state residents) over the 1980-2006 time period. Using a within-group estimator that holds constant state and year effects and exploits the variation in the repeal dates of BTRs across states, we find that BTRs are associated with a $5.7 \%$ decrease in marriage licenses issued. The within-group model would provide biased estimates of the BTR effect if repeals were correlated with trends in marriage rates. In probit models, we demonstrate that the repeal of BTRs is not correlated with changing rates of marriage or sexually transmitted diseases, suggesting that we can treat the law repeals as exogenous within our model. Since couples can obtain marriage licenses outside of their state of residence, we also use individual-level marriage license data with information on state of residence. We find that about half of the drop in marriage licenses is due to couples going out of state to get married with the other half actually being deterred from marriage. We also use birth certificate data from 1980 to 2002 for first time mothers with information on whether the mother was married at the time of birth and find that for this group, BTRs deter marriage, and the effect is larger for blacks, for young women, and for mothers without a high school degree. The marriage disincentive effect is also larger for women who are geographically further from a state without a BTR. Finally, we use Current Population Survey data from 1980 to 
2006 and look at young mothers. We again find that if there was a BTR in place at the time of the birth, the mother is less likely to be currently married.

In the next section, we discuss the literature on responses to changes in the cost of marriage, and describe in detail the BTRs we study. Section 3 describes our data sources and methods, and Section 4 presents our results. The last section concludes.

\section{Background}

\subsection{Review of Literature on Changing the Cost of Marriage}

Economic theory suggests that changes in the costs or benefits of marriage can affect marriage outcomes such as marriage rates and marriage timing (Alm, DickertConlin and Whittington, 1999; Becker, 1981). As the cost (benefit) of marriage rises, the likelihood of marriage falls (rises). Costs or benefits could be pecuniary (such as a marriage tax penalty) or non-pecuniary (security and stability). They could be one-time (such as a marriage license fee) or faced continuously during the marriage (putting the toilet seat down). Much of the theoretical literature focuses on responses to changes in the value of the marriage contract—-to bargaining power (Lundberg and Pollack, 1996), or to the division of labor (Becker, 1981).

Empirically, studies generally do find a behavioral response to changes in the cost or benefit of marriage. In particular, there is evidence that various public policies affect (whether intentionally or not) couples' incentives to marry. Moffitt (1998) provides a review of the literature examining the impact of the "marriage penalty" in the U.S., in which married couples who file jointly are taxed at a higher rate than they would be if they were single and filed separately. He concludes that most research supports a 
marriage disincentive effect. More recent research has focused on the interaction of the income tax system and transfer systems such as the EITC and welfare (Dickert-Conlin and Houser, 1998; Eissa and Hoynes, 2000; Bitler, et al. 2004). Finally, Rasul (2006) finds that unilateral divorce laws decreased marriage rates, because the laws lower the value of marriage by making it easier for one's partner to leave.

More related to this paper is the small body of work that has considered the effects of public policies that change the cost or availability of the marriage license itself. An example is the literature on the effects of minimum age requirements for a marriage license. Blank, Charles, and Sallee (2007) find that when states have a higher minimum age for marriage, some marriages are delayed. However, they also find that many young people marry out of their home state to avoid restrictive laws. Dahl (forthcoming) obtains similar results in his work using minimum age requirements as an instrument for early marriage. These laws are similar to BTRs in that they make the process of obtaining a marriage license more costly for couples who are not eligible to marry in their state but could travel to another (with the cost being effectively infinite for couples too young to marry in any state). We expect that BTRs may have similar effects-deterring marriage for some individuals, and driving others to less restrictive states to obtain their licenses. We explore both possibilities below.

\subsection{Blood Test Requirements}

Historically, many states have required applicants for a marriage license to obtain a blood test. These tests were for venereal diseases (most commonly syphilis), for genetic disorders (such as sickle-cell anemia), or for rubella. The tests for syphilis were part of a broad public health campaign enacted in the late 1930s by U.S. Surgeon General 
Thomas Parran. ${ }^{3}$ Parran argued that premarital testing was necessary to inform the potential marriage partner of the risk of contracting a communicable disease, and to reduce the risk of birth defects associated with syphilis. ${ }^{4}$ According to Brandt (1985), "by the end of 1938, twenty-six states had enacted provisions prohibiting the marriage of infected individuals" (p. 147). Screenings for genetic disorders and for rubella were also implemented in the interest of minimizing the risk of genetic disease or birth defects in the couple's offspring. ${ }^{5}$

In the case of syphilis, however, it was soon recognized that premarital blood testing was not a cost-effective way to screen for the disease. Despite reports that $10 \%$ of Americans were infected, only $1.34 \%$ of applicants in New York City's first year of testing were found to have the disease. Brandt (1985) notes that a premarital exam was "not the optimal locus for screening," since couples seeking to marry were not likely to be in the most at-risk groups, and individuals who knew they were infected could wait until the infection cleared to apply for a license. The tests became even less valuable over the 1950s, when penicillin emerged as a cheap and effective treatment for the disease. Continuing with New York City's example, early cases of syphilis dropped $90 \%$ between 1946 and 1955, and in 1976 "only 39 cases of previously undetected syphilis

\footnotetext{
${ }^{3}$ Our discussion on venereal disease draws primarily from Brandt (1985).

${ }^{4}$ Congenital syphilis is strongly linked to blindness and paralysis, and most infants born with the disease died shortly after birth (Brandt 1985).

${ }^{5}$ According to the National Network for Immunization Information, "up to $85 \%$ of expectant mothers infected in the first trimester will have a miscarriage or a baby with CRS [Congenital Rubella Syndrome]" (www.immunizationinfo.org).
} 
were found in approximately 116,000 premarital venereal examinations ... the cost of uncovering these cases was almost $\$ 60,000$ per case" (p 177). Nationwide, couples spent over $\$ 80$ million to reveal 456 cases. Similarly, the need for rubella screening lessened after vaccines for rubella were licensed in 1969. "Today there are fewer than 1,000 cases of rubella reported each year in the U.S. on average and less than 10 cases of congenital rubella syndrome" (www.immunizationinfo.org). Figure 1 shows that incidence rates of both syphilis and rubella had dropped dramatically by the late 1970s.

These reductions in the prevalence of the diseases, largely due to improvements in medical technology, led to the repeal of the requirements in many states. For example, an article noting the repeal of Massachusetts' law in 2005 reported that "there are so few syphilis cases now among engaged couples that the test is outdated and an added economic burden ... The test is also designed to detect rubella, but people are now vaccinated against that disease" (LeBlanc 2005). While we have found no systematic explanation for why individual states repealed their laws when they did, in the next section we test for possible endogeneity in the timing of the repeals. We find that the repeals are not a function of state levels of marriage rates or rates of syphilis and gonorrhea, or of trends in marriage rates.

It is important to mention that even in the early days of BTRs, there is evidence that couples took steps to avoid the tests (Brandt 1985):

After Connecticut passed its law in 1935, and before the New York Legislature had taken action, weekend marriages in New York counties bordering Connecticut rose by 55 percent . . . the number of marriages in some states reportedly declined after premarital exams became legally required. (p. 149).

There was also the view that BTRs might discourage marriage altogether: "In New 
Jersey some state legislators expressed concern that premarital laws that restricted marriage to the healthy could lead to an increase of free love, illegitimacy, and common law marriages" (p. 149). Thus, our hypothesis that BTRs might decrease marriage licenses issued by a state and possibly deter marriages finds support in the historic record. Information on BTRs used in our analysis was obtained by searching state statute volumes. In some cases, when a law was repealed, there was no record of the law in the volumes. For this reason, we supplemented our research with searches of newspaper records using Lexis-Nexis. In order to be counted as a repeal, we required that we find two separate articles referring to the repeal. Using these criteria, we identified 34 states that had a BTR in 1980. Of these 34, 19 states repealed their law in the 1980s, 7 repealed in the 1990s, and 5 more repealed between 2000 and 2006, leaving only 3 with a BTR in $2006 .{ }^{6}$ For our results, a state-year observation is coded as having a BTR if a requirement was in place for the entire calendar year. Figure 2 shows the timing of changes in BTR laws in each of the US states. ${ }^{7}$

\subsection{Blood Test Requirements and Marriage}

\footnotetext{
${ }^{6}$ In all of our analysis we classify the District of Columbia as a state.

${ }^{7}$ Both Louisiana and Illinois passed a law requiring a blood test for the HIV virus in 1988. Because the tests were expensive and identified few cases of HIV, Louisiana repealed the requirement in November of 1988 and Illinois did so in September of 1989. Because Louisiana's BTR was in place for less than six months and was enacted and repealed in the same calendar year, we code the state as never having a BTR. Illinois, however, had a BTR for syphilis in place in 1980, which was repealed along with the HIV BTR in 1989. Thus, we code Illinois as having a BTR from 1980-1988.
} 
We utilize the within-state variation produced by the repeal of blood test laws to examine the laws' impact on marriage. The presence of requirements may increase the price of obtaining a marriage license in several ways. First, in many cases there is a waiting time of at least a few days between the admission of a blood test and the receipt of the results. Calls to clinics in DC and Mississippi, the two states that still had a test in 2008, found that couples wait three to five days for the results of their tests. Additionally, a couple may need to make an appointment with their physician or local clinic to be tested. Thus, the BTRs introduce a waiting period that could prevent couples who decide to marry on the "spur-of-the-moment" from doing so. ${ }^{8}$

Further, the presence of a BTR may increase the price of obtaining a marriage license. To comply with a requirement, individuals applying for a marriage license must pay for the doctor's visit and blood test in most cases, which "can cost couples hundreds of dollars" (Leblanc 2005). Clinics in DC and Mississippi reported per-couple costs of $\$ 40$ and $\$ 26$, respectively; in DC, tests from a doctor's office were reported to cost as much as $\$ 200$ per couple. Additionally, the Mississippi clinic we called indicated that

\footnotetext{
${ }^{8}$ While we have no data on the prevalence of spur-of-the-moment marriages, we do observe the day of the week and type of ceremony in our marriage license data. In 1980, $10.6 \%$ of marriages were civil ceremonies that took place between Monday and Thursday, suggesting that a nontrivial portion of marriages are not of the (presumably planned) weekend-church-wedding-variety. Also, in the 1984 Detroit Area Survey of 459 evermarried women age $18-75,10.9 \%$ of the women report that they were never engaged before marrying (White 1990).
} 
Medicaid could not be used to cover the cost of the test. There may be other financial costs associated with obtaining the test, including the opportunity cost of the time spent.

Finally, there may be psychic costs associated with a BTR. As Bowman (1977) observes (referring to tests for sickle-cell anemia), "the mandatory testing for carriers of genetically determined diseases at the time of marriage application can result in serious psychological trauma, for the decision has already been made to marry." Applicants may wish to avoid learning about their disease status, or may want to keep this information from their partners. There may also be non-negligible disutility from a visit to the doctor, or from the procedure of having blood drawn. Taken together, we believe these costs may have made a BTR a deterrent to obtaining a marriage license in states with the laws, and may have also decreased couples' likelihood of marrying at all.

In Figure 3, we provide some graphical evidence of the impact of BTRs on marriage rates. In this figure, we graph the number of marriage licenses issued per 1,000 state residents, before and after the repeal of a BTR. Data are from the CDC's reports of state marriage rates (described in more detail in the next section). The solid line plots the average of the marriage rates for 25 states that had a requirement in place in 1980, but who repealed their law by 2001 . We center the figure at the year the law was repealed in each state and report the marriage rates for the five years before and after the repeal of the law. The dotted line represents a "control" group of 16 states that did not have a blood test law at any time between 1980 and $2001 .^{9}$ For this group, the mean marriage rate $t$ years from repeal is calculated using an average of marriage rates in years in which a law was repealed in another state, following Ayers and Levitt (1998).

\footnotetext{
${ }^{9}$ Ten states are not included in the figure; see the data appendix.
} 
There are three notable results in Figure 3. First, there is a similar downward trend in marriage rates in both the treatment and control states in the pre-treatment period . In the differences-in-differences framework that we will use for our empirical estimates, it is important that the trends for the treatment and control groups be the same in the absence of the intervention, and this appears to be the case. Second, this

downward trend appears to be interrupted in the year that treated states repeal their BTRs. Between the year before the test is repealed and the year after, an average increase in marriage licenses of about 3\% is observed. This increase persists in the years following the repeal, and it appears that in the long run marriage rates remain above the pre-repeal trend and are close to the rates for states with no BTR over this period. Third, the control states show no break in the downward trend in marriage rates. In the next section, we describe our empirical strategy for confirming these results and for examining the impact of the requirements on marriages more generally.

\section{Data and Methods}

We will be using within- state variation in whether states require a blood test for a marriage license to examine the impact of the laws on marriage behavior. The general specification is:

$$
y_{s t}=\beta_{0}+\beta_{1} * \text { bloodtest }_{s t}+\alpha_{s}+\delta_{t}+\tau_{s} \text { time }_{t}+\varepsilon_{s t}
$$

where bloodtest $_{\text {st }}$ is a dummy variable equal to one if state $s$ had a blood test for the entire year in year $t, \alpha_{\mathrm{s}}$ represents state fixed-effects, $\delta_{\mathrm{t}}$ are year dummies, time $\mathrm{t}_{\mathrm{t}}$ is a quadratic time trend, $\tau_{\mathrm{s}}$ gives the state-specific coefficient on the time trend, and $\varepsilon_{\mathrm{st}}$ is random error. The dependent variable will be a measure of marriage behavior in state $s$ 
and period $t$ and will vary with the particular data set and specification. Because errors may be serially correlated within state, we estimate heteroskedastic, robust standard errors that are clustered at the state level.

As with any identification strategy using variation in state laws, one must be concerned with the exogeneity of the laws. Our results will be biased if the presence of a law or timing of a repeal is correlated with unobserved state characteristics. To address this, we include state fixed effects and state-specific quadratic trends in all of our preferred specifications. We also include year dummies in all specifications, to allow for any secular trends in marriage rates. As further checks on the exogeneity of the laws, we test whether the timing of the repeals can be predicted by observed state characteristics, and we consider the effects of adding a placebo law to our main results.

We use four different panel data sets in our analysis. ${ }^{10}$ First, we use annual state marriage rates obtained from the CDC's Vital Statistics data for 1980-2006. Marriage rates are defined as the number of marriage licenses issued per 1,000 state residents. Thus, estimating equation (1) using these marriage rates as the dependent variable will tell us whether the laws had any effect on the number of marriage licenses issued by states. The advantage of this data set is that it is available for the entire time period we are interested in studying, and for all states. States might also be interested in knowing the effects of the laws on license applications, since marriage license fees are a source of revenue for local and state governments. However, even if we see that the laws decrease marriage licenses, we will not be able to identify decreases in actual marriages using this

${ }^{10}$ See the data appendix for detailed information on data sources. 
data set - couples in states with requirements could still be marrying but obtaining their licenses in another state. Furthermore, this data is not available at a more detailed level (for example, subdivided into racial or education categories).

For these reasons, we also use the Marriage and Divorce Detail Files from Vital Statistics, which contain individual-level data from marriage licenses. The data are available from 1981 to 1995 , and not all states report their individual license data (see the data appendix). However, the data is ideal for analyzing the impact of a change in blood tests on marriage, as both the state of residence and state of marriage are reported. Thus, we are able to examine the impact of BTRs on marriage licenses issued per 1,000 state residents, even if the couple married in another state. This allows us to see if the laws actually deterred marriage, as opposed to simply sending residents out of state for their marriage licenses. Also, because these are micro data we are able to construct marriage rates by racial group. ${ }^{11}$ Finally, we can use the data to see whether the laws affect couples' likelihood of marrying in their state of residence or in an adjoining state.

We supplement our analysis using the Vital Statistics Natality Detail files for 1980-2002. The data contain a virtual census of births to women in the United States, with about four million births per year. For most states women are asked to report whether or not they are married at the time of birth, and we use this data to obtain both

\footnotetext{
${ }^{11}$ We also constructed marriage rates by education, but because education is only reported on the marriage license data through 1988, those results are not reported here.
} 
marriage and birth information for women over $18 .{ }^{12,13}$ We choose this group because first-time mothers are plausibly "at-risk" for marriage, so the BTRs might have a larger effect on this population. These mothers are also important for policy makers interested in rates of out-of-wedlock childbearing or in outcomes for children born in and out of marriage. ${ }^{14}$ The model is similar to equation (1), but the dependent variable is a binary variable equal to one if the mother is married at the time of birth. We include controls for mother's race and education, and we divide the sample to test the hypothesis that the BTRs have a greater effect on low-SES women. We also present results using a distance measure of women's access to a marriage license without a blood test requirement.

Finally, we turn to estimating the effect of the laws on respondents' reported relationship status in the Current Population Survey from 1980 to 2006 . This allows us to examine the effect of BTRs on marriage in a fourth data set, and to also consider the effects of BTRs on women below the poverty line. For comparability with the birth certificate results, we restrict our sample mothers aged 19-24, for a sample of 45,531 women.

\section{Results}

${ }^{12}$ In states where the mothers are not asked the marriage questions directly, marital status is imputed by the NCHS. In 1980, marital status is imputed for seven states; by 2006, only two states (MI and NY) still impute marital status.

${ }^{13}$ The age restriction is imposed to avoid the effects of states' minimum age laws

${ }^{14}$ For example, Oklahoma's 1999 Marriage Initiative has "the ultimate goal of increasing child well-being" (www. Okmarriage.org). 


\subsection{Effect of Laws on Marriage Licenses Issued}

We first estimate the effect of states' BTRs on the number of marriage licenses issued by the state. The results in Table 1 are based on data from CDC reports of state marriage rates from 1980-2006 - the same data that were used to create Figure 3. Results Each coefficient in the table is the estimate of the effect of the presence of a BTR on the number of marriage licenses issued per 1,000 state residents $\left(\beta_{1}\right.$ in equation (1)). We report our results with and without state-specific time trends, and we exclude Hawaii and Nevada from all specifications because of high marriage rates. We exclude California from some specifications because of a policy that allowed residents to obtain confidential marriage licenses that did not require a blood test. We find that including California weakens the impact of the BTR, as would be expected if California's BTR was not binding. Therefore, we will drop California in all other results. We also find that the inclusion of state-specific time trends can significantly affect the coefficients. Many states were experiencing dramatic declines in marriage rates over this period, largely due to social and cultural forces. If these changes coincided with the repeal of the BTRs, we might erroneously attribute decreases in marriage rates to those repeals. As such, for the remainder of the paper we focus on results with state-specific time trends.

We find that for the 1980-2006 period, BTRs decrease marriage licenses issued by 0.502 per 1,000 state residents in our preferred specification with state-specific time trends and with California omitted. This corresponds to a 5.7\% decrease in response to a BTR. In the bottom two panels of Table 1, the sample is split at 1995 to examine the effect of the laws in the earlier and later years of the time period. We choose 1995 as the dividing point for comparability with results using license data in Tables 3 and 4 (in 
Section 4.2). We see that the negative effect of BTRs on marriage licenses issued is larger post-1995, where the coefficient -0.5568 reflects a $6.8 \%$ decrease in marriage licenses issued. We might expect BTRs to have a larger effect in later years for several reasons. The stigma of cohabiting may have lessened in the later period, so that couples are more likely to decide to live together rather than marry in response to a BTR. Decreases in travel costs may have made it easier to travel to another state to obtain a license. Finally, as more states repeal their laws, couples have more options when looking to marry in a state that does not require a test.

As mentioned in the discussion of our empirical strategy, the above results are biased if the presence of a BTR or the timing of a repeal is correlated with unobserved state characteristics. While we cannot test this directly, we perform two exercises that suggest that the repeals can be treated as exogenous. First, we estimate a probit model to test whether observed characteristics impact the probability that a state repeals its BTR, conditional on having not yet repealed. ${ }^{15}$ The estimated equation is as follows:

$$
\text { repeal }_{s t}=\theta_{0}+\theta_{1} X_{s t-1}+\theta_{2} Z_{s t-1}+\theta_{3} X_{s t-1} * \text { time }_{t}+v_{s t}
$$

where repeal $l_{s t}$ is equal to one if state s repealed a BTR in year $\mathrm{t}$ and zero otherwise. $X_{s t-1}$ is the one-year lagged state marriage rate (defined as above), and $X_{s t-1} * t_{i m e}$ is the statespecific quadratic marriage rate trend. $Z_{s t-1}$ is a vector of one-year lagged state rates of gonorrhea and syphilis; rates of gonorrhea and syphilis are from the CDC and are defined as the number of reported instances per 100,000 people. The random error is $v_{s t}$. The

\footnotetext{
${ }^{15}$ The specification is similar to that in Goldin and Rouse (2000), who use a probit model to determine whether observable characteristics predict that an orchestra will adopt a blind audition format.
} 
sample begins in 1981 with all states with a BTR in place (excluding Hawaii and California), and states exit the sample once a law is repealed. The results are presented in Table 2. We find that these variables are not predictors of the repeal of a law-the coefficients are neither statistically nor practically significant.

As a second test, we reproduce the results in Table 1 while adding a placebo law that is repealed two years before each state's actual repeal. We would expect these placebos to have an effect if states repealed their BTRs in response to changes in marriage rates (so that there is reverse causality in Equation 1). These results are in Appendix Table 7. We find that the placebo law is never statistically significant, and that the effects of the BTRs are virtually unchanged.

The results in this section show that states' repeals of their BTRs were plausibly exogenous, and that BTRs had a large and statistically significant effect on marriage licenses issued by a state. Policy makers might be interested in this finding, since marriage license fees are a source of revenue for state and local governments. However, while these results are consistent with the hypothesis that BTRs actually deter marriage, we cannot test this directly with this data. It is possible that the observed decrease in licenses issued is driven by couples who are still getting married, but are just doing so in another state. To study the effect of BTRs on the likelihood of marriage, we turn to results using individual marriage license data.

\subsection{Effect of Laws on Marriages to State Residents}

The results in Table 3 are based on state marriage rates constructed from individual-level marriage license data. This data includes information on the bride and groom's state of residence, and as long as the couple marries in a reporting state, we 
observe the marriage. This allows us to approximate the number of marriages per 1,000 state residents, as opposed to the number of marriage licenses issued by the state (as in Table 1). The actual number of marriages observed will be an underestimate, since not all states report individual-level license data. The fact that not all states report will only bias our results if couples that choose to marry out of state in response to BTRs are more likely to marry in non-reporting states than other couples who marry out of state. ${ }^{16}$ The individual level data also allow us to examine marriage rates by racial group.

First, when state marriage rates are constructed using the groom's state of residence, we see a decrease of 0.2500 marriages per 1,000 residents in response to BTRs, or a $2.8 \%$ decrease in the marriage rate. Compare this to the result in column (4) of Table 1, which finds a 6.1\% decrease in marriage licenses issued between 1980 and 1995. Taking these two results together, it appears that about half of the decrease in licenses is due to couples marrying out of state, while about half choose not to marry at all. Also, we can compare this result to that of Alm and Whittington (1999), who consider the effects of the marriage tax penalty. They find a $2.3 \%$ decrease in the probability that a woman marries in response to a $10 \%$ rise in the penalty, where the mean marriage penalty for women in their sample is $\$ 2,620$. Considering that the dollar cost of a BTR can be as high as \$200 (and keeping in mind that many of the costs of a BTR are non-pecuniary), our estimate of a $2.8 \%$ decrease in the marriage rate in response to a BTR is quite close to that of Alm and Whittington.

Though the results for blacks are imprecise, the point estimates for racial groups suggest that the BTRs may be more of a deterrent to marriage for blacks than for whites.

${ }^{16}$ The non-reporting states are AZ, AR, NV, NM, ND, OK, TX, and WA. 
The coefficient -0.3419 represents a $4.4 \%$ decrease in marriage rates for blacks, while the effect for whites is a $3.3 \%$ decrease. When the sample is restricted to marriages where the groom is under age 30 , the effect of the laws is generally greater in magnitude. These results suggest that BTRs do have more of an impact on lower-SES groups, who might find the economic or other costs of the tests to be a greater deterrent. The results are similar when state marriage rates are constructed using the bride's state of residence. ${ }^{17}$

To further explore the issue of couples marrying in other states in response to a BTR, we use data on state of residence and state of marriage to examine the laws' impact on couples' likelihood of marrying in their state of residence or in an adjoining state. These results are reported in Table 4. In Panel A, the dependent variable is constructed by taking the total number of marriages to a state's residents as the denominator, and the number of those marriages that took place in the state as the numerator. We see that the percent of couples marrying in the groom's state of residence was $1.5 \%$ lower when the groom's state had a BTR in place. For grooms under 30, we also see lower in-state marriage rates, though the coefficients are generally smaller. The fact that older grooms are less likely to marry in-state in response to the requirements may be due to their ability

${ }^{17}$ Appendix Table 8 replicates the exercise in Table 3 but with a measure of distance from the state population centroid to the nearest state line where a blood test can be obtained without a license as the policy variable. Results are shown for the full population using groom's state of residence. While these results are less precise, they suggest that residents with further to go to a no-requirement state are less likely to be married. The coefficient for whites is $-0.1158(\mathrm{se}=0.0519)$, indicating that a 100 -mile increase in this distance decreases the marriage rate for whites in the state by $1.21 \%$. 
to bear the costs of an out-of-state marriage. Results are very similar when the bride's state of residence is used.

The results in Panel B show the effect of BTRs on couples' likelihood of marrying in an adjoining state. We see that the percent of couples marrying in an adjoining state is $9.4 \%$ higher when a requirement is in place. The magnitude of the coefficients in Panel B is slightly less than the corresponding coefficients in Panel Asuggesting that when couples are driven out of state for their marriage licenses, most marry in an adjoining state, while a few travel even further away. ${ }^{18}$

The estimates using the Vital Statistics Marriage License data show that BTRs send residents out of state for marriage licenses and in some cases deter marriage altogether. We now look to confirm the marriage-deterrent effect of BTRs using two alternative data sets.

\subsection{Effect of Laws on Marital Status of First-Time Moms}

Using the Vital Statistics Natality Detail data, we measure the effect of the laws on the fraction of first-time mothers who are married. Data are collapsed to the state-year level and results are reported in Table 5. First, consider the results in Panel A, for which the specification is again as in Equation 1. For all mothers over 18, the coefficient for the

${ }^{18}$ Appendix Table 9 replicates the exercise in Table 4 using our distance measure as the policy variable, for the full population using groom's state of residence. Also, the sample is restricted to states with a BTR in place. These results are imprecise, but accord with intuition - among couples who did marry, when the distance to a state without a BTR was greater, they were more likely to marry in-state and less likely to marry in an adjoining state. 
presence of a BTR in the year of the birth is negative, though not statistically significant. However, for women of lower socioeconomic status, the effect is both statistically and economically meaningful. BTRs decrease the likelihood of marriage by $2.8 \%$ for black women, by $3.5 \%$ for women without a high school degree, and by $1.3 \%$ for women under 25. The effect for blacks is comparable to but slightly smaller than the $4.4 \%$ effect observed using marriage license data (perhaps because the marriage decisions of new mothers are less likely to be affected along this margin). ${ }^{19}$ Again, we find that the laws have a greater effect on low-SES groups.

In Panel B of Table 5, we consider an alternative measure of our policy variable. The variable "distance" is the distance, in hundreds of miles, from the state's population centroid to the nearest state without a BTR. For state-years with a blood test requirement for this period, the mean distance in miles is 111 , the median is 95 , and the range is 4 to 466. Arguably, a BTR in one's home state should be less of a barrier to marriage if a state without a BTR is nearby. While we have generated results for our other estimates using this variable (see Appendix Tables), we believe the effect of distance may be particularly important for pregnant women, for whom travel may be especially difficult.

The results in Panel B confirm this. For all first-time mothers, a 100-mile increase in the distance to a no-BTR state decreases the likelihood of being married by $0.23 \%$. Again the effect is larger for blacks (-1.36\%), for young women $(-0.75 \%)$, and for women without a high school degree (-3.53\%).

\subsection{Effect of Laws on Young Mothers in the CPS}

\footnotetext{
${ }^{19}$ When studying the effects of EITC payments on marriage, Eissa and Hoynes (2000) suggest that couples with children are less likely to be affected.
} 
Finally, we use a fourth data set to confirm the marriage-deterrent effect of BTRs. The Current Population Survey from 1980 to 2006 contains information on marital status and several other demographic measures, including poverty status (which was not available in the birth certificate data). For comparability with the birth certificate results, we limit the sample to young women with children. We use women who are age 19 to 24 , since the birth certificate results suggest that these women are most likely to be affected by a BTR.

Table 6 shows the results from a linear probability model that controls for race/ethnicity, age, and education. The results are imprecise, but again suggest that a BTR reduces the likelihood that a young mother is married. The percent effects are quite close to those for the birth certificate results, particularly for women without a high school degree. The results for blacks are an exception; in the CPS we observe a much larger percent effect of a BTR on the probability of marriage. The imprecision of these results leads us to prefer the birth certificate estimates (which have 2000 times more observations), but we take the CPS results as further evidence of a negative effect of BTRs on marriage. ${ }^{20}$

\footnotetext{
${ }^{20}$ Results using distance as the policy variable are in Appendix Table 10. Again, greater distance to a state without a BTR is associated with decreased rates of marriage, though the effects are small and generally statistically insignificant. We have also produced results for all women (not just mothers) using the CPS data; we find a small and statistically insignificant negative effect of a BTR on marriage rates for women with lowsocioeconomic status.
} 


\section{Conclusion}

In this paper, we consider the effect of the repeal of states' blood test requirements for marriage licenses on marriage. We use a within-group estimator that holds constant state and year effects and exploits the variation in the dates of BTRs across states. We begin with panel data on state marriage rates between 1980 and 2006, and show that blood test requirements decrease marriage licenses issued by a state by $5.7 \%$. We also show that the repeals are not correlated with state marriage or STD rates, or in trends in marriage rates, suggesting that we can treat the law repeals as exogenous within our models. We then use individual-level marriage license data from 1981 to 1995 to confirm that for this period, about half of the decrease in licenses issued by the states was due to couples going out of state for their licenses, while the rest was due to couples deciding not to marry at all. We also use birth certificate data and Current Population Survey data to show that for young mothers, the likelihood of being married was lower in states with a blood test requirement. This result is stronger for individuals who are black, young, or without a high school degree.

Policy makers who are interested in promoting marriage may find these results useful when predicting the impact of policies that change the cost of marriage. While the issue of blood tests themselves is no longer relevant in most cases (Missouri and D.C. being exceptions), other policies that change the cost of marriage include required premarital counseling, waiting periods, and license fees. For example, in 2008, Texas initiated a "Twogether in Texas" program that requires premarital counseling to avoid a waiting period and $\$ 60$ fee for a marriage license (www.twogetherintexas.com). We have shown that even small changes in the cost of marriage can have significant effects, 
particularly for certain populations. This result might also generalize to policies such as tax and transfer programs, where previous research has had difficulty in isolating the disincentive effects of changing costs.

These results may also be important for social scientists studying the effects of marriage on other outcomes, including health, labor force participation, economic wellbeing, and fertility. Establishing causality in this literature has been a significant challenge, as researchers have had difficulty finding an appropriate instrumental variable for marriage (Ribar 2004). One instrument that has been used is exogenous changes in sex ratios produced by immigration waves (Angrist 2002) or male incarceration rates (Charles and Luoh 2007). Also, a recent study by Dahl and Moretti (2008) uses child's gender to show that women pregnant with males are more likely to get married. However, use of these instruments to estimate the causal impacts of marriage can be limited by the somewhat narrowly defined treated population (e.g. immigrant populations in the early $20^{\text {th }}$ century, pregnant women).

Our results indicate that blood test requirements provide plausibly exogenous within- and across-state variation in the cost of marriage, and thus might be used to identify the causal effects of marriage. Because the tests were originally enacted in the interest of public health but were repealed after they became obsolete, the effects of the policy change should not directly affect other outcomes such as labor force participation, earnings, or fertility. Further, the BTRs were repealed over a long and recent period in U.S. history and potentially affect the entire population of couples considering marriage in the affected states - though the fact that the laws have the greatest impact for low-SES groups suggests that this strategy might be particularly helpful to researchers studying the 
effects of marriage for these groups. Along this line, Buckles and Price (2009) use BTRs as an instrument for marriage to study the effect of marriage on infant health for low-SES women. 


\section{DATA APPENDIX}

1. Information on state blood test requirements was obtained from state statute volumes. A complete list of volumes used is available upon request. We supplemented our research with searches of newspaper records using Lexis-Nexis. In order to be counted as a repeal, we required that we find two separate articles referring to the repeal.

2. The distance variable used in Table 5 and Appendix Tables 8, 9, and 10 was constructed using 2000 population centroids, from the United States Census Bureau: http://www.census.gov/geo/www/cenpop/statecenters.txt. We then used Google Maps to estimate the driving distance from the centroid (given by latitude and longitude) to the nearest state line without a BTR.

2. CDC-Reported Marriage Rates from 1975-2006 were obtained from the website of the Center for Disease Control's National Center for Health Statistics: http://www.cdc.gov/nchs/\#.

In Figure 3, using this data, ten states are not included. Hawaii and Nevada are omitted because of high marriage rates; California and Oklahoma are omitted for missing data; Connecticut, Georgia, Massachusetts, the District of Columbia, Mississippi, and Montana are omitted because each still had a law in place as of 2002.

3. Marriage License Data from 1981-1995 are from the Vital Statistics Marriage and Divorce Detail Files and are available at http://www.nber.org/data/marrdivo.html. States that do not report marriage license data include Arizona, Arkansas, Nevada, New Mexico, North Dakota, Oklahoma, Texas, and Washington.

Marriage rates, including those by race, are created using population estimates from the United States Census Bureau: http://www.census.gov/popest/states/. These population estimates are also used when weighting the data by state population.

4. Birth Certificate Data (the Natality Detail Files) for 1980-2002 are from the Center for Disease Control's National Center for Health Statistics. They are available for download at http://www.nber.org/data/vital-statistics-natality-data.html.

5. Current Population Survey data for 1980 to 2006 were obtained from IPUMS: http://www.census.gov/cps/.

6. Gonorrhea and syphilis rates used in Table 1 and Figure 1 were constructed using disease prevalence data from the Center for Disease Control (see references) and state population data from the Census Bureau. 


\section{REFERENCES}

Ahituv and Lerman. 2007. "How do marital status, work effort, and wage rates interact?" Demography, 44(3).

Alm, James, Stacy Dickert-Conlin and Leslie A. Whittington. 1999. "Policy Watch: The Marriage Penalty," The Journal of Economic Perspectives, 13(3): 193-204.

Alm, James and Leslie A. Whittington. 1999. "For Love or Money? The Impact of Income Taxes on Marriage," Economica, 66(263): 297-316.

Angrist, Joshua. 2002. "How Do Sex Ratios Affect Marriage and Labor Markets? Evidence from America's Second Generation," The Quarterly Journal of Economics, 117(3): 997-1038.

Ayers, Ian and Steven D. Levitt. 1998. "Measuring Positive Externalities from Unobservable Victim Precaution: An Empirical Analysis of Lojack." The Quarterly Journal of Economics, 113(1): 43-77.

Becker, Gary. 1981. A Treatise on the Family. Cambridge, Massachusetts: Harvard University Press.

Bitler, Marianne, Jonah Gelbach, Hilary Hoynes, Madeline Zavodny. 2004. "The Impact of Welfare Reform on Marriage and Divorce." Demography, 41(2): 213-236.

Blanchflower and Oswald. 2004. "Well-being over time in Britain and the USA." Journal of Public Economics, 88.

Blank, Rebecca; Kerwin Charles, and James Sallee. 2007. "Do State Laws Affect the Age of Marriage? A Cautionary Tale About Avoidance Behavior" NBER working paper $\# 13667$.

Bowman, James. 1977. "Genetic Screening Programs and Public Policy." Phylon, 38(2), $117-142$.

Brandt, Allan M. 1985. No Magic Bullet: A Social History of Venereal Disease in the United States Since 1880. New York, New York: Oxford University Press.

Buckles, Kasey and Joseph Price. 2009. “Marriage and Infant Health.” Unpublished manuscript.

Centers for Disease Control and Prevention. 2007. "Sexually Transmitted Disease Surveillance 2006." Atlanta, GA: U.S. Department of Health and Human Services.

Centers for Disease Control and Prevention. 1997. "Summary of Notifiable DiseasesUnited States, 1996.” MMWR 2007; 45(53).

Centers for Disease Control and Prevention. 2007. "Summary of Notifiable Diseases- 
United States, 2006.” MMWR 2007; 55(53).

Charles and Luoh. 2007. "Male Incarceration, the Marriage Market and Female Outcomes." mimeo.

Clark and Etile. 2006. "Don't Give up on Me Baby: Spousal Correlation in Smoking Behavor." Journal of Health Economics, 25(5).

Dahl, Gordon. forthcoming. "Early Teenage Marriage and Future Poverty." Demography.

Dahl, Gordon and Enrico Moretti. 2008. "The Demand for Sons." Review of Economic Studies, 75(4): 1085-1120.

Dickert Conlin, Stacy and Scott Houser. 1998. "Taxes and Transfers: A New Look at the Marriage Penalty," National Tax Journal, 51(2): 175-218.

Duncan, Wilkerson, and England. 2006. "Cleaning Up Their Act: The Effects of Marriage and Cohabitation on Licit and Illicit Drug Use." Demography, 43(4).

Eissa, Nada and Hillary Hoynes. 2000. "Explaining the Fall and Rise in the Tax Cost of Marriage: The Effect of Tax Laws and Demographic Trends, 1984-1997", National Tax Journal, 53, 683-711.

Felder. 2006. "The Gender Longevity Gap: Explaining the Difference Between Singles and Couples". Journal of Population Economics. 19(3).

Frech and Williams. 2007. "Depression and the Psychological Benefits of Entering Marriage." Journal of Health and Social Behavior, 48(2).

Goldin, C. and C. Rouse. 2000. "Orchestrating Impartiality: The Impact of "Blind" Auditions on Female Musicians." American Economic Review, 90:715-41.

Kenney and McLanahan. 2006. "Why Are Cohabiting Relationships More Violent Than Marriages?” Demography, 43(1).

Korenman and Neumark. 1991. "Does Marriage Really Make Men More Productive?" The Journal of Human Resources, 26(2).

LeBlanc, Steve. February 3, 2005. "Bay State Abolishes Blood Test for Marriage License." The Standard-Times: A5.

Liu and Heiland. 2008. "Should We Get Married? The Effect of Parents' Marriage on Out-of-Wedlock Children." Economic Inquiry.

Liu and Umberson. 2008. "The Times They Are a Changin': Marital Status and Health Differentials from 1972 to 2003." The Journal of Health and Social Behavior, 49(3).

Lundberg, Shelly and Robert Pollack. 1996. "Bargaining and Distribution in Marriage." 
Journal of Economic Perspectives, 10(4): 139-158.

Moffit, Robert. 1998. Welfare, the Family, and Reproductive Behavior: Research Perspectives. National Academy Press.

National Toxicology Program, U.S. Department of Health and Human Services. 2007. "Rubella." http://cerhr.niehs.nih.gov/common/rubella.html.

Rasul, Imran. 2006. "Divorce laws and Marriage Markets." Journal of Law, Economics, and Organization, 22(1), 30-69.

Ribar, David. 2004. "What Do Social Scientists Know About the Benefits of Marriage? A Review of Quantitative Methodologies." IZA Discussion Paper No. 998.

Waite, Linda. 1995. “Does Marriage Matter?” Demography, 32(4).

White, Martin. 1990. Detroit Area Study, 1984: The Process of Mate Choice and Nuptiality in Detroit. Ann Arbor, MI: ICPSR.

www.okmarriage.org. "Oklahoma Marriage Initiative,” accessed April 14, 2009.

www.twogetherintexas.com. "New Law Promotes Free Marriage Education Classes," accessed February 25, 2009.

www.immunizationinfo.org/vaccineInfo. "Vaccine Information: Rubella," accessed February 26, 2009.

Zimmerman and Easterlin. 2006. "Happily Ever After? Cohabitation, Marriage, Divorce, and Happiness in Germany." Population and Development Review, 32(3). 
Figure 1. Incidence of Syphilis and Rubella in the United States, 1941-2006 (Cases per 100,000)

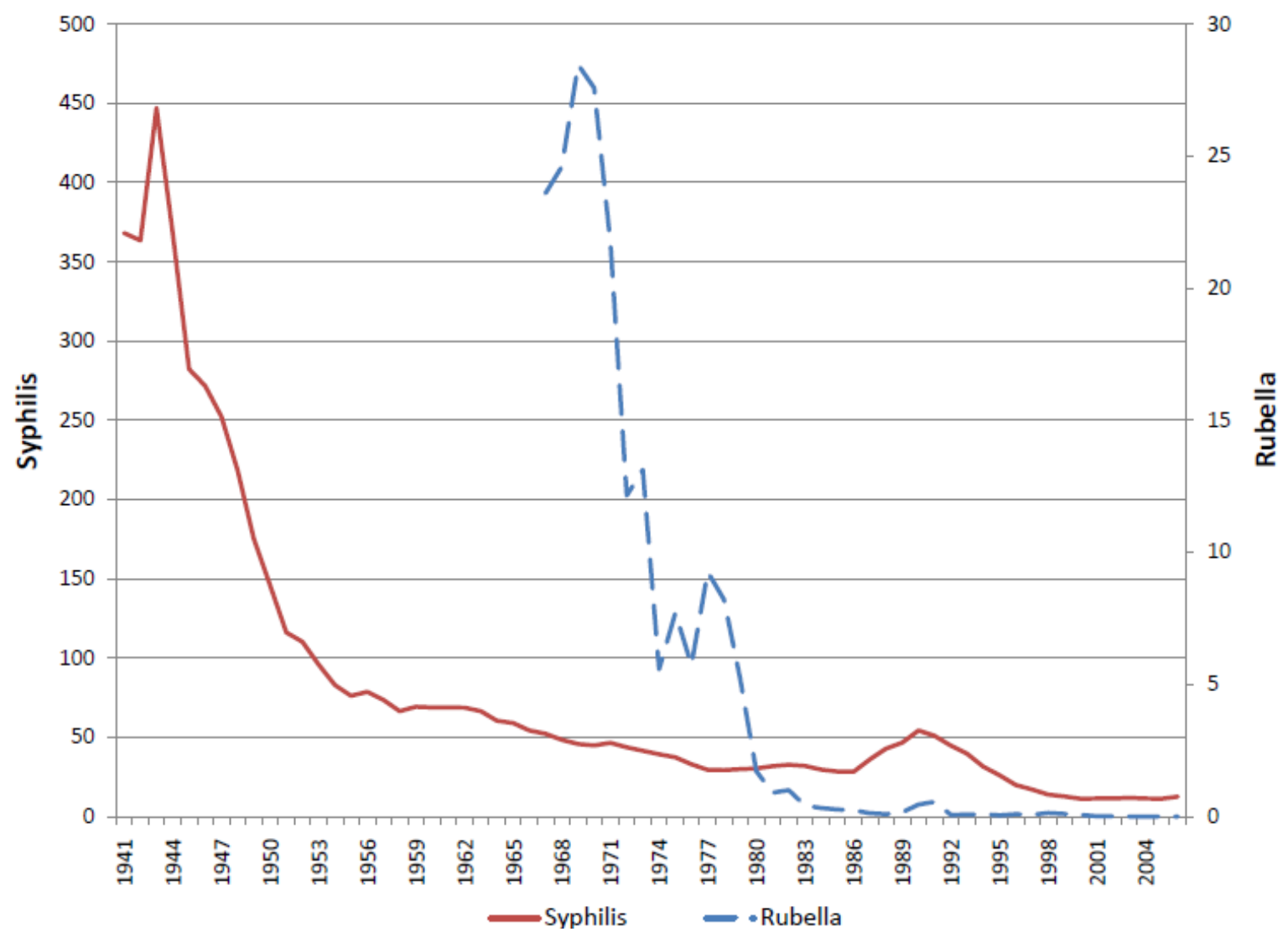

Source: "Sexually Transmitted Disease Surveillance 2006" (CDC 2007a); "Summary of Notifiable Diseases-United States, 1996" (CDC 1997); "Summary of Notifiable Diseases-United States, 2006" (CDC 2007b). 
Figure 2. Timing of Blood Test Requirement Repeals 1980-2006

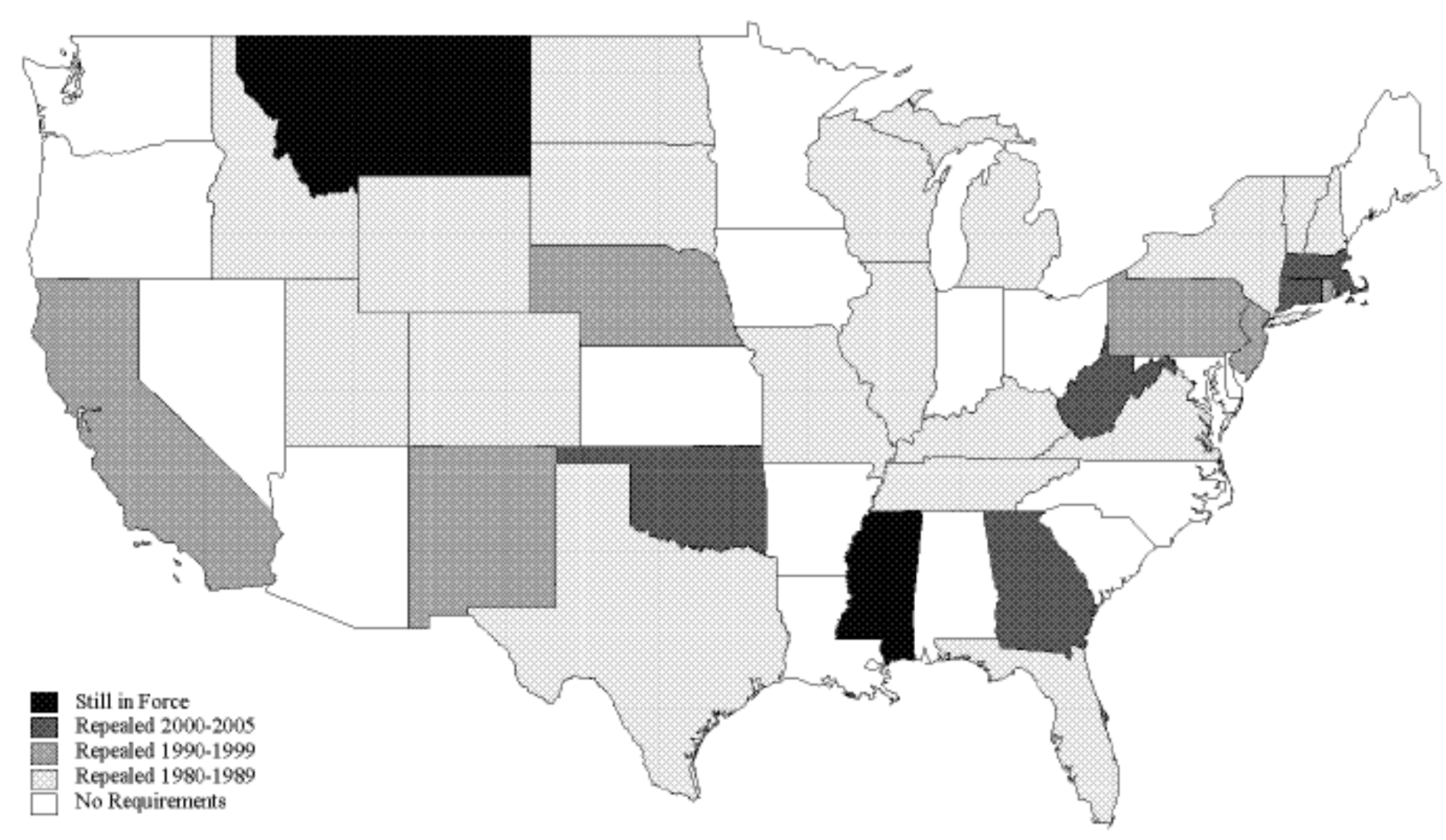

Source: State Statute Volumes. 
Figure 3. Effect of Blood Test Requirement Repeal on Marriage Licenses Issued

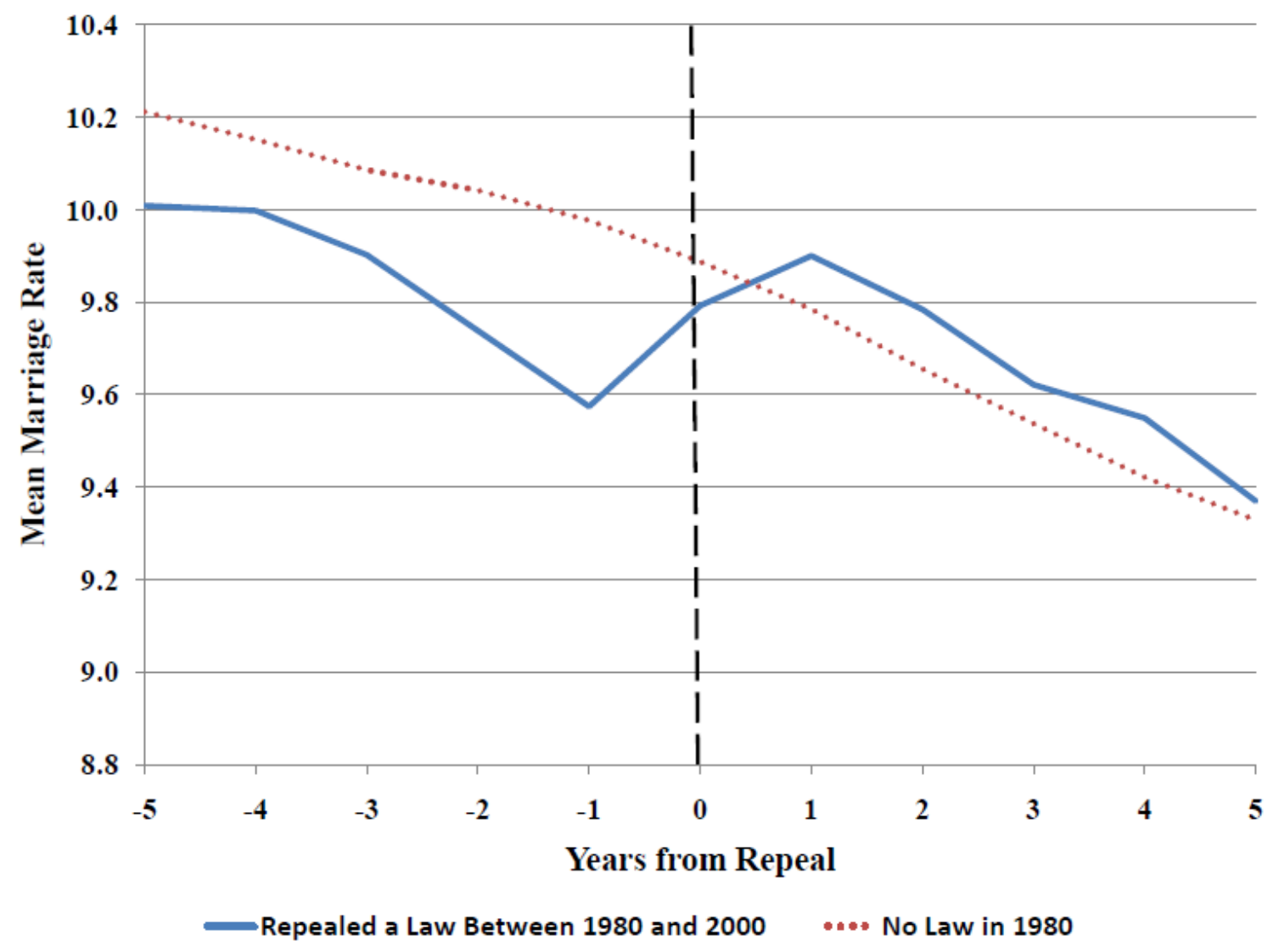

Source: CDC reports of state marriage rates, 1975-2005. The solid line is the average marriage rate for 25 states that had a blood test requirement in place in 1980 but who repealed the law by 2000 . The data for each state is centered at the year the law was repealed. The dotted line corresponds to the 16 states that did not have a blood test requirement in 1980, where the mean marriage rate $t$ years from repeal is calculated using an average of marriage rates in years in which a law was repealed in another state, following Ayers and Levitt (1998). Ten states are not included in the figure for reasons addressed in the data appendix. 
Table 1. Effect of Blood Test Laws on Number of Marriage Licenses Issued by the State, per 1,000 State Residents

\begin{tabular}{lcccc}
\hline & All & Omit CA & All & Omit CA \\
\hline \hline 1980-2006: & & & & \\
Blood Test & & & & \\
Requirement & $-0.4741^{* *}$ & $-0.5755^{* *}$ & $-0.3403^{* *}$ & $-0.5016^{* *}$ \\
Average Marriage Rate & $(0.1782)$ & $(0.1839)$ & $(0.1559)$ & $(0.1338)$ \\
[\% Change] & 8.57 & 8.76 & 8.57 & 8.76 \\
\hline 1980-1995: & {$[-5.53 \%]$} & {$[-6.57 \%]$} & {$[-3.97 \%]$} & {$[-5.73 \%]$} \\
Blood Test & & & & \\
Requirement & $-0.4532 * *$ & $-0.5404 * *$ & $-0.3905^{* *}$ & $-0.4226^{* *}$ \\
Average Marriage Rate & $(0.2213)$ & $(0.2310)$ & $(0.1325)$ & $(0.1441)$ \\
[\% Change] & 9.38 & 9.55 & 9.38 & 9.55 \\
\hline 1996-2006: & {$[-4.83 \%]$} & {$[-5.66 \%]$} & {$[-4.16 \%]$} & {$[-6.06 \%]$} \\
Blood Test & & & & \\
Requirement & $-0.7849 * *$ & $-0.8422^{* *}$ & $-0.5552^{* *}$ & $-0.5568 * *$ \\
Average Marriage Rate & $(0.1350)$ & $(0.1280)$ & $(0.2169)$ & $(0.2111)$ \\
[\% Change] & 7.56 & 7.75 & 7.56 & 8.17 \\
\hline State and Year Fixed Effects & Yes & Yes & Yes & Yes \\
State-Specific Time Trends & No & No & Yes & Yes \\
\hline
\end{tabular}

$*$ Indicates significance at $10 \% ; * *$ indicates significance at $5 \%$. Each coefficient is from a separate regression, where the coefficient is on a dummy indicating whether the state had a blood test requirement in place for the entire year. Standard errors are clustered at the state level and are in parenthesis. Observations are at the state-year level and data are from CDC reports of state marriage rates, defined as the number of marriage licenses issued per 1,000 people. Regressions are weighted by state population. Nevada and Hawaii are dropped from all specifications because of high marriage rates (52.8 and 22.3 respectively in 2006). California is dropped from the second and fourth specifications because of a policy that allowed residents to obtain confidential marriage licenses that did not require a blood test. 
Table 2. Estimated Probit Models for the Repeal of a Blood Test Requirement

\begin{tabular}{|c|c|c|c|}
\hline & [1] & [2] & [3] \\
\hline Marriage Rate ${ }_{t-1}$ & $\begin{array}{c}0.0269 \\
(0.0419) \\
{[0.0039]}\end{array}$ & $\begin{array}{c}0.0525 \\
(0.0434) \\
{[0.0069]}\end{array}$ & $\begin{array}{c}-0.0072 \\
(0.1107) \\
{[-0.0009]}\end{array}$ \\
\hline Gonorrhea Rate ${ }_{t-1}$ & & $\begin{array}{c}-0.0003 \\
(0.0006) \\
{[-0.0000]}\end{array}$ & $\begin{array}{c}-0.0004 \\
(0.0007) \\
{[-0.0001]}\end{array}$ \\
\hline Syphilis rate $t-1$ & & $\begin{array}{c}-0.0163 \\
(0.0158) \\
{[-0.0021]}\end{array}$ & $\begin{array}{c}-0.0157 \\
(0.0169) \\
{[-0.0019]}\end{array}$ \\
\hline $\mathrm{t}$ & & & $\begin{array}{c}-0.3249 \\
(0.2365) \\
{[-0.0394]}\end{array}$ \\
\hline$t^{2}$ & & & $\begin{array}{l}0.0152^{*} \\
(0.0086) \\
{[0.0018]}\end{array}$ \\
\hline Marriage Rate $_{\text {t-1 }} \mathbf{x ~ t}$ & & & $\begin{array}{c}0.0357 \\
(0.0261) \\
{[0.0043]}\end{array}$ \\
\hline Marriage Rate ${ }_{\mathrm{t}-1} \mathbf{x} \mathrm{t}^{2}$ & & & $\begin{array}{c}-0.0017 \\
(0.0011) \\
{[-0.0002]}\end{array}$ \\
\hline Pseudo $\mathrm{R}^{2}$ & 0.0016 & 0.0317 & 0.0548 \\
\hline Observations & 356 & 355 & 355 \\
\hline
\end{tabular}

* Indicates significance at the $10 \%$ level. The dependent variable is equal to one if the state repealed a blood test requirement in that year and zero otherwise. Standard errors are clustered at the state level and are in parenthesis, marginal effects are in brackets. Observations are at the state-year level. The sample is all states with a law in 1981, and states exit the sample once a law is repealed. Marriage rates are from CDC reports, defined as the number of marriage licenses issued per 1,000 people. STD rates are from the CDC, defined as the number of instances per 100,000 people. Hawaii is dropped because of its high marriage rate (22.3 in 2006), and California is dropped because of a policy that allowed residents to obtain confidential marriage licenses that did not require a blood test. 


\section{Table 3. Effect of Blood Test Laws on Number of Marriages}

per 1,000 State Residents

\begin{tabular}{|c|c|c|c|c|}
\hline & All & White & Black & Other \\
\hline $\begin{array}{l}\text { By Groom's State } \\
\text { of Residence }\end{array}$ & $\begin{array}{l}-0.2500 * * \\
(0.0819)\end{array}$ & $\begin{array}{l}-0.3132 * * \\
(0.0826)\end{array}$ & $\begin{array}{l}-0.3419 \\
(0.5233)\end{array}$ & $\begin{array}{l}-0.2683 * * \\
(0.0905)\end{array}$ \\
\hline $\begin{array}{c}\text { By Groom's State, } \\
\text { Age }<30 \text { Only }\end{array}$ & $\begin{array}{l}-0.3136^{*} \\
(0.1627)\end{array}$ & $\begin{array}{l}-0.5954 * * \\
(0.1330)\end{array}$ & $\begin{array}{l}-0.4171 \\
(0.4703)\end{array}$ & $\begin{array}{l}-0.2511 * \\
(0.0888)\end{array}$ \\
\hline $\begin{array}{l}\text { By Bride's State } \\
\text { of Residence }\end{array}$ & $\begin{array}{l}-0.2556 * * \\
(0.0893)\end{array}$ & $\begin{array}{l}-0.3008 * * \\
(0.0896)\end{array}$ & $\begin{array}{l}-0.3344 \\
(0.5029)\end{array}$ & $\begin{array}{l}-0.2725 * * \\
(0.1018)\end{array}$ \\
\hline State and Year Fixed Effects & Yes & Yes & Yes & Yes \\
\hline State-Specific Time Trends & Yes & Yes & Yes & Yes \\
\hline $\begin{array}{l}\text { Mean by Groom's State, } \\
\text { All Ages } \\
{[\% \text { Change }]}\end{array}$ & $\begin{array}{c}9.10 \\
{[-2.75 \%]}\end{array}$ & $\begin{array}{c}9.62 \\
{[-3.26 \%]}\end{array}$ & $\begin{array}{c}7.86 \\
{[-4.35 \%]}\end{array}$ & $\begin{array}{c}2.42 \\
{[-11.09 \%]}\end{array}$ \\
\hline \# State-Year Cells & 629 & 507 & 507 & 507 \\
\hline
\end{tabular}

* Indicates significance at 10\%; ** indicates significance at 5\%. The dependent variable is number of observed marriages for state residents, per 1,000 residents. Standard errors are clustered at the state level and are in parenthesis. Observations are at the state-year level, and data are from Vital Statistics Marriage License Records for reporting states, from 1981-1995. Regressions are weighted by population. For the regressions done by race, states are also omitted if race is not reported on the license. Maine is omitted in 1995 due to data errors. California is omitted because of a policy that allowed residents to obtain confidential marriage licenses that did not require a blood test. State-specific time trends are quadratic. 
Table 4. Effect of Blood Test Laws on Where Marriage License is Obtained

Panel A: Effect of Blood Test Laws on Fraction Marrying In State of Residence

\begin{tabular}{llllc}
\hline & All & White & Black & Other \\
\hline \hline By Groom's State & $-0.0129^{* *}$ & $-0.0143^{* *}$ & $-0.0142^{*}$ & $-0.1073^{*}$ \\
of Residence & $(0.0023)$ & $(0.0017)$ & $(0.0037)$ & $(0.0515)$ \\
By Groom's State, & $-0.0092^{* *}$ & $-0.0063^{* *}$ & -0.0064 & $-0.1425^{* *}$ \\
Age $<30$ Only & $(0.0013)$ & $(0.0015)$ & $(0.0054)$ & $(0.0552)$ \\
By Bride's State & $-0.0119^{* *}$ & $-0.0145^{* *}$ & $-0.0141^{* *}$ & $-0.0776^{* *}$ \\
of Residence & $(0.0024)$ & $(0.0016)$ & $(0.0040)$ & $(0.0358)$ \\
\hline State and Year Fixed Effects & Yes & Yes & Yes & Yes \\
State-Specific Time Trends & Yes & Yes & Yes & Yes \\
\hline Mean by Groom's State, & 0.8810 & 0.9031 & 0.9085 & 0.9183 \\
All Ages & {$[-1.46 \%]$} & {$[-1.58 \%]$} & {$[-1.56 \%]$} & {$[-11.68 \%]$} \\
[\% Change] & 629 & 507 & 507 & 507 \\
\# State-Year Cells & & & & 5 \\
\hline
\end{tabular}

Panel B: Effect of Blood Test Laws on Fraction Marrying in Adjoining State

\begin{tabular}{lcccc}
\hline & All & White & Black & Other \\
\hline \hline By Groom's State & $0.0069^{* *}$ & $0.0121^{* *}$ & 0.0071 & $0.0639^{*}$ \\
of Residence & $(0.0029)$ & $(0.0023)$ & $(0.0045)$ & $(0.0331)$ \\
By Groom's State, & $0.0047^{* *}$ & $0.0056^{* *}$ & -0.0007 & $0.0877^{* *}$ \\
Age<30 Only & $(0.0013)$ & $(0.0016)$ & $(0.0062)$ & $(0.0341)$ \\
By Bride's State & $0.0071^{* *}$ & $0.0119^{* *}$ & $0.0128^{*}$ & $0.0468^{* *}$ \\
of Residence & $(0.0031)$ & $(0.0023)$ & $(0.0056)$ & $(0.0161)$ \\
\hline State and Year Fixed Effects & Yes & Yes & Yes & Yes \\
State-Specific Time Trends & Yes & Yes & Yes & Yes \\
\hline $\begin{array}{l}\text { Mean by Groom's State, } \\
\text { All Ages }\end{array}$ & 0.0736 & 0.0633 & 0.0672 & 0.0464 \\
[\% Change] & {$[9.38 \%]$} & {$[19.12 \%]$} & {$[10.57 \%]$} & {$[137.72 \%]$} \\
\# State-Year Cells & 629 & 507 & 507 & 507 \\
\hline
\end{tabular}

* Indicates significance at $10 \%$; ** indicates significance at $5 \%$. Standard errors are clustered at the state level and are in parenthesis. Observations are at the state-year level, and data are from Vital Statistics Marriage License Records for reporting states, from 1981-1995. Regressions are weighted by population. For the regressions done by race, states are also omitted if race is not reported on the license. Maine is omitted in 1995 due to data errors. California is omitted because of a policy that allowed residents to obtain confidential marriage licenses that did not require a blood test. State-specific time trends are quadratic. 


\section{Table 5: Effect of Blood Test Laws on Marital Status of}

First-Time Mothers Ages 19+

Panel A: Effect of Presence of a Blood Test Requirement

\begin{tabular}{lcccc}
\hline & All Mothers & Black Mothers & $<$ HS Degree & $<25$ years old \\
\hline Blood Test & -0.002 & $-0.010^{* *}$ & $-0.017^{* *}$ & $-0.008^{* *}$ \\
& $(0.003)$ & $(0.003)$ & $(0.006)$ & $(0.003)$ \\
Black & $-0.406^{* *}$ & & $-0.357^{* *}$ & $-0.415^{* *}$ \\
& $(0.012)$ & & $(0.022)$ & $(0.016)$ \\
HS graduate & $0.200^{* *}$ & $0.135^{* *}$ & & $0.122^{* *}$ \\
& $(0.009)$ & $(0.004)$ & & $(0.007)$ \\
Age of Mother & $0.026^{* *}$ & $0.036^{* *}$ & $0.020^{* *}$ & $0.064^{* *}$ \\
& $(0.001)$ & $(0.001)$ & $(0.001)$ & $(0.002)$ \\
\hline Mean Marriage Rate & 0.7456 & 0.3518 & 0.4823 & 0.6038 \\
$\quad$ for Sample & {$[-0.27 \%]$} & {$[-2.84 \%]$} & {$[-3.52 \%]$} & {$[-1.32 \%]$} \\
[\% Change] & 79,443 & 30,710 & 32,398 & 22,207 \\
\# State-Year-Age-Race & & & & \\
lls & 0.812 & 0.817 & 0.811 & 0.933 \\
$\mathrm{R}^{2}$ & & &
\end{tabular}

Panel B: Effect of Distance from State Population Centroid to Nearest State with no Requirement All Mothers $\quad$ Black $\quad<$ HS Degree $<25$ years old Mothers

\begin{tabular}{lcccc}
\hline \hline Distance in miles/100 & $-0.0017^{*}$ & $-0.0045^{* *}$ & -0.0056 & $-0.0045^{* *}$ \\
& $(0.0010)$ & $(0.0018)$ & $(0.0034)$ & $(0.0018)$ \\
Black & $0.1996^{* *}$ & $0.1353^{* *}$ & & $0.1217^{* *}$ \\
& $(0.0093)$ & $(0.0040)$ & & $(0.0072)$ \\
HS graduate & $-0.4070^{* *}$ & & $-0.3568^{* *}$ & $-0.4164^{* *}$ \\
& $(0.0125)$ & & $(0.0225)$ & $(0.0156)$ \\
Age of Mother & $0.0258^{* *}$ & $0.0355^{* *}$ & $0.0203^{* *}$ & $0.0635^{* *}$ \\
& $(0.0008)$ & $(0.0013)$ & $(0.0013)$ & $(0.0025)$ \\
\hline Mean Marriage Rate & 0.7456 & 0.3309 & 0.4823 & 0.6037 \\
$\quad$ for Sample & {$[-0.23 \%]$} & {$[-1.36 \%]$} & {$[-3.53 \%]$} & {$[-0.75 \%]$} \\
$\begin{array}{l}\text { [\% Change] } \\
\text { \# State-Year-Age- }\end{array}$ & 77,140 & 30,074 & 31,649 & 21,517 \\
ce Cells & & & & \\
$\mathrm{R}^{2}$ & 0.813 & 0.818 & 0.813 & 0.934 \\
\hline
\end{tabular}

* Indicates significance at 10\%; ** indicates significance at 5\%. Standard errors are clustered at the state level and are in parenthesis. The unit of observation is the state-year-age-race specific cell. Regressions are weighted by the number of mothers in each group. Each regression includes state and year fixed effects and state specific quadratic time trends. Data are from Natality Detail Files, 1980-2002. California is omitted because of a policy that allowed residents to obtain confidential marriage licenses that did not require a blood test. 
Table 6. Effects of Blood Test Laws on Marital Status of Mothers Age 19-24

\begin{tabular}{lcccc}
\hline & All Mothers & Black Mothers & $<$ HS Degree & Poor \\
\hline Blood Test & -0.0143 & $-0.0824^{*}$ & -0.0242 & -0.0233 \\
& $(0.0121)$ & $(0.0410)$ & $(0.0226)$ & $(0.0178)$ \\
Age & $0.0317^{* *}$ & $0.0342^{* *}$ & $0.0248^{* *}$ & $0.0197^{* *}$ \\
& $(0.0017)$ & $(0.0029)$ & $(0.0030)$ & $(0.0022)$ \\
Black & $-0.4186^{* *}$ & & $-0.4728^{* *}$ & $-0.3766^{* *}$ \\
& $(0.0127)$ & & $(0.0198)$ & $(0.0130)$ \\
Hispanic & 0.0226 & & 0.0367 & $0.0467^{*}$ \\
& $(0.0168)$ & & $(0.0278)$ & $(0.0239)$ \\
Other & $-0.0617^{* *}$ & & -0.0547 & $-0.0658^{*}$ \\
& $(0.0264)$ & & $(0.0476)$ & $(0.0367)$ \\
HS Graduate & $0.0415^{* *}$ & $0.1111^{* *}$ & & -0.0101 \\
& $(0.0099)$ & $(0.0138)$ & & $(0.0105)$ \\
\hline State and Year Fixed Effects & Yes & Yes & Yes & Yes \\
State-Specific Time Trends & Yes & Yes & Yes & Yes \\
\hline Mean Marriage Rate for Sample & 0.6413 & 0.3002 & 0.6179 & 0.4953 \\
[\% Change] & {$[-2.23 \%]$} & {$[-27.45 \%]$} & {$[-3.92 \%]$} & {$[-4.70 \%]$} \\
Observations & 45531 & 35352 & 7597 & 22546 \\
$\mathrm{R}^{2}$ & 0.2267 & 0.1588 & 0.2372 & 0.2107 \\
\hline
\end{tabular}

* Indicates significance at $10 \%$; ** indicates significance at $5 \%$. Standard errors are clustered at the state level and are in parenthesis. Data are from the 1980-2006 Current Population Survey. California is omitted because of a policy that allowed residents to obtain confidential marriage licenses that did not require a blood test. Includes state and year fixed effects and quadratic state-specific time trends. The blood test variable indicates whether a blood test was in place in that state in the year of the survey. 


\section{Appendix}

Table 7: Effect of Blood Test Laws on Number of Marriage Licenses Issued by the State, per 1,000 State Residents, with Placebo Law

\begin{tabular}{|c|c|c|c|c|}
\hline & All & Omit CA & All & Omit CA \\
\hline \multicolumn{5}{|l|}{ Panel A: 1980-2006 } \\
\hline $\begin{array}{l}\text { Blood Test } \\
\text { Requirement }\end{array}$ & $\begin{array}{l}-0.7013 * * \\
(0.2362)\end{array}$ & $\begin{array}{l}-0.6931 * * \\
(0.2803)\end{array}$ & $\begin{array}{l}-0.4232 * * \\
(0.1280)\end{array}$ & $\begin{array}{l}-0.5088 * * \\
(0.1367)\end{array}$ \\
\hline Placebo & $\begin{array}{c}0.3396 \\
(0.2912)\end{array}$ & $\begin{array}{c}0.1800 \\
(0.3228)\end{array}$ & $\begin{array}{c}0.2660 \\
(0.2269)\end{array}$ & $\begin{array}{c}0.0286 \\
(0.2032)\end{array}$ \\
\hline \multicolumn{5}{|l|}{ Panel B: 1980-1995: } \\
\hline $\begin{array}{l}\text { Blood Test } \\
\text { Requirement }\end{array}$ & $\begin{array}{l}-0.6131 * * \\
(0.2635)\end{array}$ & $\begin{array}{l}-0.5717 * * \\
(0.2956)\end{array}$ & $\begin{array}{l}-0.3936 * * \\
(0.1297)\end{array}$ & $\begin{array}{l}-0.4206^{* *} \\
(0.1380)\end{array}$ \\
\hline Placebo & $\begin{array}{c}0.3172 \\
(0.3139)\end{array}$ & $\begin{array}{c}0.0613 \\
(0.3371)\end{array}$ & $\begin{array}{l}-0.1093 \\
(0.1806)\end{array}$ & $\begin{array}{l}-0.2545 \\
(0.1682)\end{array}$ \\
\hline \multicolumn{5}{|l|}{ Panel C: 1996-2006: } \\
\hline $\begin{array}{l}\text { Blood Test } \\
\text { Requirement }\end{array}$ & $\begin{array}{l}-0.8379 * * \\
(0.1771)\end{array}$ & $\begin{array}{l}-0.8727 * * \\
(0.1732)\end{array}$ & $\begin{array}{l}-0.5387 * * \\
(0.2007)\end{array}$ & $\begin{array}{l}-0.5441 * * \\
(0.1965)\end{array}$ \\
\hline Placebo & $\begin{array}{c}0.1102 \\
(0.3071)\end{array}$ & $\begin{array}{c}0.0638 \\
(0.3029)\end{array}$ & $\begin{array}{c}0.1543 \\
(0.3044)\end{array}$ & $\begin{array}{c}0.1188 \\
(0.2829)\end{array}$ \\
\hline $\begin{array}{l}\text { State and Year Fixed } \\
\text { Effects } \\
\text { State-Specific Time Trends }\end{array}$ & $\begin{array}{l}\text { Yes } \\
\text { No }\end{array}$ & $\begin{array}{l}\text { Yes } \\
\text { No }\end{array}$ & $\begin{array}{l}\text { Yes } \\
\text { Yes }\end{array}$ & $\begin{array}{l}\text { Yes } \\
\text { Yes }\end{array}$ \\
\hline
\end{tabular}

* Indicates significance at 10\%; ** indicates significance at 5\%. For regression details and mean marriage rates, see notes to Table 1. For the regressions in this table, we add a placebo variable that is a two-year lead of the blood test variable. 
Table 8. Effect of Distance to State with no Blood Test Requirement on Number of Marriages per 1,000 State Residents

\begin{tabular}{lcccc}
\hline & All & White & Black & Other \\
\hline \hline $\begin{array}{l}\text { Distance in miles/100 } \\
\text { of Residence }\end{array}$ & $\begin{array}{c}-0.0816 \\
(0.0522)\end{array}$ & $\begin{array}{l}-0.1158^{* *} \\
(0.0519)\end{array}$ & $\begin{array}{c}0.2154 \\
(0.1449)\end{array}$ & $\begin{array}{c}-0.0379 \\
(0.0432)\end{array}$ \\
\hline $\begin{array}{l}\text { State and Year Fixed Effects } \\
\text { State-Specific Time Trends }\end{array}$ & Yes & Yes & Yes & Yes \\
\hline $\begin{array}{l}\text { Mean by Groom's State, } \\
\text { All Ages }\end{array}$ & 9.09 & Yes & Yes & Yes \\
$\begin{array}{l}\text { [\% Change] } \\
\text { \# State-Year Cells }\end{array}$ & {$[-0.90 \%]$} & {$[-1.21 \%]$} & {$[2.75 \%]$} & {$[-2.01 \%]$} \\
\hline
\end{tabular}

** Indicates significance at 5\%. For regression details, see notes to Table 3. Coefficients are for the independent variable "distance", which is the distance in hundreds of miles from the state population centroid to the nearest state line where a blood test is not required. Sample is constructed using groom's state of residence, for all ages.

Additionally, Hawaii and Alaska are omitted because they do not border other states. 
Table 9. Effect of Distance to State with no Blood Test Requirement on Where Marriage License is Obtained

\begin{tabular}{lcccc}
\hline & All & White & Black & Other \\
\hline \hline $\begin{array}{l}\text { Dependent Variable }=1 \\
\text { If Married In State of }\end{array}$ & 0.0096 & 0.0011 & 0.0090 & 0.0490 \\
$\quad(0.0106)$ & $(0.0107)$ & $(0.0144)$ & $(0.0465)$ \\
$\begin{array}{l}\text { Residence } \\
\text { Sample Mean }\end{array}$ & 0.8231 & 0.8840 & 0.8993 & 0.8809 \\
[\% Change] & {$[1.17 \%]$} & {$[0.12 \%]$} & {$[1.00 \%]$} & {$[5.56 \%]$} \\
\hline $\begin{array}{l}\text { Dependent Variable }=1 \\
\text { If Married In Adjoining }\end{array}$ & -0.0094 & -0.0009 & 0.0011 & -0.0418 \\
State & $(0.0081)$ & $(0.0091)$ & $(0.0127)$ & $(0.0417)$ \\
$\begin{array}{l}\text { Sample Mean } \\
\text { [\% Change] }\end{array}$ & 0.1246 & 0.0817 & 0.0697 & 0.0746 \\
\hline State and Year Fixed Effects & Yes & Yes & {$[1.58 \%]$} & {$[-56.03 \%]$} \\
State-Specific Time Trends & Yes & Yes & Yes & Yes \\
\hline \# State-Year Cells & 223 & 172 & Yes & Yes \\
\hline
\end{tabular}

** Indicates significance at 5\%. For regression details, see notes to Table 4. Coefficients are for the independent variable "distance", which is the distance in hundreds of miles from the state population centroid to the nearest state line where a blood test is not required. Sample is constructed using groom's state of residence, for all ages. Additionally, sample is limited to states with a blood test requirement in place, and Hawaii and Alaska are omitted because they do not border other states. 
Table 10. Effects of Distance to State with no Blood Test Requirement on Marital Status of Mothers Age 19-24

\begin{tabular}{lcccc}
\hline & All Mothers & Black Mothers & $<$ HS Degree & Poor \\
\hline \hline Distance in Miles/100 & -0.0000 & $-0.0005^{* *}$ & -0.0001 & -0.0000 \\
Age & $(0.0000)$ & $(0.0002)$ & $(0.0001)$ & $(0.0001)$ \\
& $0.0316^{* *}$ & $0.0342^{* *}$ & $0.0247^{* *}$ & $0.0196^{* *}$ \\
Black & $(0.0018)$ & $(0.0029)$ & $(0.0030)$ & $(0.0022)$ \\
& $-0.4196^{* *}$ & & $-0.4732^{* *}$ & $-0.3772^{* *}$ \\
Hispanic & $(0.0127)$ & & $(0.0198)$ & $(0.0130)$ \\
& 0.0223 & & 0.0367 & $0.0463^{*}$ \\
Other & $(0.0168)$ & & $(0.0279)$ & $(0.0239)$ \\
& $-0.0522^{*}$ & & -0.0524 & -0.0579 \\
HS Graduate & $(0.0268)$ & & $(0.0492)$ & $(0.0382)$ \\
& $0.0416^{* *}$ & $0.1112^{* *}$ & & -0.0102 \\
State and Year Fixed Effects & $(0.0100)$ & $(0.0138)$ & & $(0.0105)$ \\
State-Specific Time Trends & Yes & Yes & Yes & Yes \\
\hline Mean Marriage Rate for Sample & Yes & Yes & Yes & Yes \\
[\% Change] & 0.6407 & 0.2991 & 0.6173 & 0.4945 \\
Observations & $-0.00 \%]$ & {$[-0.17 \%]$} & {$[-0.01 \%]$} & {$[-0.00 \%]$} \\
R ${ }^{2}$ & 45531 & 35352 & 7597 & 22546 \\
\hline
\end{tabular}

* Indicates significance at 10\%; ** indicates significance at 5\%. For regression details, see notes to Table 6. Coefficients are for the independent variable "distance", which is the distance in hundreds of miles from the state population centroid to the nearest state line where a blood test is not required. Hawaii and Alaska are omitted because they do not border other states. 